\title{
Antifungal and antiaflatoxigenic activities of coumarinyl thiosemicarbazides against Aspergillus flavus NRRL 3251
}

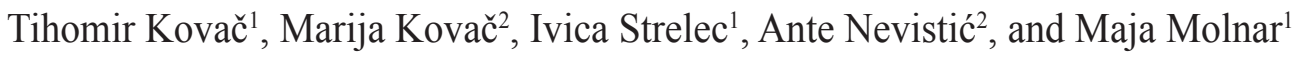 \\ Department of Applied Chemistry and Ecology, Faculty of Food Technology, Josip Juraj Strossmayer University of \\ Osijek, Osijek ${ }^{1}$, Inspecto Ltd., Električne centrale 1, Đakovo², Croatia
}

[Received in September 2016; Similarity Check in September 2016; Accepted in February 2017]

The antifungal and antiaflatoxigenic effects of two series of coumarinyl thiosemicarbazides on Aspergillus flavus NRRL 3251 were studied. Fungi were grown in YES medium for $72 \mathrm{~h}$ at $29^{\circ} \mathrm{C}$ in the presence of $0,0.1,1$, and $10 \mu \mathrm{g} \mathrm{mL}^{-1}$ of coumarinyl thiosemicarbazides: one series with substitution in position 7 and another with substitution in position 4 of the coumarin core. Dry mycelia weight determination was used for antifungal activity estimation, while the aflatoxin B1 content in YES media, determined by the dilute and shoot LC-MS/MS technique, was used for the antiaflatoxigenic effect estimation. Standard biochemical assays were used for oxidative status marker (TBARS, SOD, CAT, and GPX) determination in A. flavus NRRL 3251 mycelia. Results show that 7-substituted-coumarinyl thiosemicarbazides possess a better antifungal and antiaflatoxigenic activity than 4-substituted ones. The most prominent substituted compound was the compound 3, $N$-(4-chlorophenyl)-2-(2-((4-methyl-2-oxo-2H-chromen-7-yl)oxy)acetyl)hydrazine-1-carbothioamide, which completely inhibited aflatoxin production at the concentration of $10 \mu \mathrm{g} \mathrm{mL}^{-1}$. Oxidative stress response of A. flavus exposed to the selected compounds points to the modulation of oxidative stress as a possible reason of aflatoxin production inhibition.

KEY WORDS: coumarins; aflatoxins; antimycotoxigenic activity; oxidative status modulation; dilute and shoot LC-MS/ MS technique

Microorganisms in food and feed cause their spoilage, leading to hazards to human and animal health, as well as to significant crop losses (1). Fungi have become one of the main food contaminants, affecting food appearance and food safety, especially those classified as mycotoxin producers. Aspergillus flavus Link, a well-known aflatoxin producer, has become a serious problem in Europe in the last few decades. This is due to its greater occurrence in agricultural products and to crop infection with toxic and carcinogenic aflatoxins caused by global climate changes $(2,3)$. Aflatoxin risk to human health is associated with direct consumption of infected and processed products where aflatoxins persist after technological processes (1).

The fact that pathogens can develop resistance to some antimicrobial agents (4) underscores the importance of discovering new, more potent agents (5). According to Zani et al. (2), synthetic fungicides are still the most effective agents in the control of mycotoxin production by Aspergillus species. Synthetic thiosemicarbazides and coumarins have shown a wide spectrum of biological activities, antifungal being only one of these.

The antifungal and antimycotoxigenic effects of some synthetic thiosemicarbazone derivatives on Aspergillus and Fusarium species was reported by Degola et al. (1), emphasizing the importance of compound functionalisation.

Correspondence to: Maja Molnar, Phone: +385 31224 342; Fax: +385 31207 115; E-mail: maja.molnar@ptfos.hr
Pelosi (6) highlighted the significance of thiosemicarbazones and their metal complexes as biologically active compounds, possessing a wide array of biological activities, including antifungal activity. Combining thiosemicarbazides with Mannich bases, both of these possessing antifungal activity, Pishawikar et al. (7) showed that their combination had a significant impact on Aspergillus niger.

Coumarins, both natural and synthetic, were found to possess a significant antifungal activity on Aspergillus species. Seselin, a natural coumarin derivative isolated from the aerial part of Decatropis bicolor, was reported as a potent $A$. flavus antifungal agent during maize storage (8). Natural coumarins from the seeds of Aegle marmelos Correa, as well as their synthetic analogues, were found to possess significant antifungal activity (9). Šarkanj et al. (10) have found that some coumarinyl thiosemicarbazides show antifungal activity, depending on functionalisation, while Guerra et al. (11) have found that 6-nitro-7-hydroxycoumarin possesses antifungal activity against Aspergillus species, possibly by affecting the fungal cell wall structure. However, while the antifungal activities of natural and synthetic coumarins are widely investigated, there are still limited reports on their antiaflatoxigenic activity.

Considering all of the abovementioned, the aim of the present study was to investigate the effect of some novel coumarinyl thiosemicarbazides as possible antifungal and antiaflatoxigenic compounds. In addition, we also investigated the effect of the most promising antiaflatoxigenic 
and antifungal coumarinyl thiosemicarbazides on the oxidative stress modulation within fungal cells.

\section{MATERIALS AND METHODS}

\section{Chemicals}

Glutathione reductase (GR) from baker's yeast ( $S$. cerevisiae) (100-300 $\mathrm{U} \mathrm{mg}^{-1}$ protein), superoxide dismutase (SOD) from bovine erythrocytes (3000 $\mathrm{U} \mathrm{mg}^{-1}$ protein), xanthine oxidase from bovine milk (0.4-1.0 $\mathrm{U} \mathrm{mg}^{-1}$ protein), ethylenediaminetetraacetic acid tetrasodium salt, nitrotetrazolium blue chloride (NBT), xanthine, and potassium cyanide were purchased from Sigma Aldrich (Germany). A stabilised $3 \%$ solution of hydrogen peroxide was purchased from Fluka (Germany), $\beta$-nicotinamide adenine dinucleotide 2 '-phosphate reduced tetrasodium salt (NADPH) from Serva (Germany), and ethylenediaminetetraacetic acid disodium salt (EDTA-2Na) from Pharmacia Biotech (Sweden). Acetonitrile and dimethyl sulfoxide (DMSO) were purchased from J.T. Baker (Italy), yeast extract (YES) from Biolife (Italy), while aflatoxin standard mix (AFB1, AFG1, AFB2, and AFG2) from Biopure (Austria). Sodium azide and hydrochloric acid were purchased from Merck (Germany), trichloroacetic acid from Kemika (Croatia), ethanol absolute from Panreac (Spain), and butylated hydroxytoluene and 2-thiobarbituric acid were purchased from Acros Organics (USA). All other chemicals were of p.a. quality and purchased from commercial suppliers.

\section{Synthesis of target compounds}

Compounds were synthesised as reported by Šarkanj et al. (2013) (10).

\section{Antioxidant activity}

Antioxidant activity of synthesised compounds was performed according to Šarkanj et al. (2013) (10) and expressed as the 2,2-diphenyl-1-picrylhydrazyl (DPPH) scavenging activity. Briefly, $750 \mu \mathrm{L}$ of a $0.2 \mathrm{mM}$ solution of compounds was mixed with $750 \mu \mathrm{L}$ of $0.2 \mathrm{mM}$ DPPH solution. It was then incubated for 30 minutes and absorbance was measured at $517 \mathrm{~nm}$.

\section{Antifungal and antiaflatoxigenic assay}

For antifungal activity determination, $A$. flavus NRRL 3251 mycelia were grown submersed in YES medium $(2 \%$ yeast extract and $6 \%$ sucrose, $\mathrm{pH} 5.8)(12,13)$, with addition of synthesised compounds (dissolved in DMSO) to obtain the final concentrations of $0,0.1,1$, and $10 \mu \mathrm{g} \mathrm{mL}$ ${ }^{1}$. Conidia suspensions $\left(2.5 \times 10^{6} \mathrm{CFU} \mathrm{mL}^{-1}\right)$ were prepared according to Šarkanj et al. (10). The final concentration of DMSO in the growth media was $0.1 \%$. The mycelia were grown on a rotary shaker (KS 260 basic, IKA, Germany) set to $200 \mathrm{rpm}$, during $72 \mathrm{~h}$ at $29^{\circ} \mathrm{C}$ (14). After $72 \mathrm{~h}$ of growth, wet mycelia were separated from YES medium by filtration through a filter paper. Part of mycelia was dried until a constant mass $\left(24 \mathrm{~h}\right.$ at $\left.105^{\circ} \mathrm{C}\right)$ was obtained to determine dry mycelia weight. The rest of mycelia were lyophilised for further analysis. Only the mycelia grown in the presence of compounds exhibiting significant inhibition of aflatoxin production ( $>25 \%$ ) was used for fungal cell oxidative status analysis.

For the investigation of antiaflatoxigenic activity of the synthesised compounds, a quantitative analysis of the aflatoxin content in culture filtrates by a "dilute and shoot" method was performed. YES medium was diluted ten-fold in mobile phases after filtration through a nylon syringe filter $(0.22 \mu \mathrm{m}$, Labex, Hungary) and without further cleanup injected into a UPLC-MS/MS system. Chromatographic analyses were performed in an Acquity UPLC H-Class system (Waters, MA, USA) using an Acquity BEH C18 column $(2.1 \times 100 \mathrm{~mm}, 1.7 \mu \mathrm{m})$ (Waters, USA) with a gradient elution consisting of eluent A (water with $0.1 \%$ formic acid) and eluent B (acetonitrile with $0.1 \%$ formic acid). The eluent $A$ was held at $98 \%$ for the first $0.5 \mathrm{~min}$, followed by a decrease to $10 \%$ over $4.0 \mathrm{~min}$. It was then held for $0.5 \mathrm{~min}$ at $10 \%$, followed by an increase to $98 \%$ for $4.6 \mathrm{~min}$, and equilibration for another $1.6 \mathrm{~min}$, to give a total run time of $6 \mathrm{~min}$. The flow rate was set to $0.5 \mathrm{~mL}$ $\min ^{-1}$ and the column temperature was maintained at $40{ }^{\circ} \mathrm{C}$. Aliquots of $10 \mu \mathrm{L}$ of prepared samples were injected into the chromatographic system. MS/MS detection was performed using a Xevo TQD tandem quadrupole mass spectrometer (Waters, MA, USA), equipped with an electrospray ionisation interface (ESI) operating in the positive ion mode. For each aflatoxin ion, two transitions were monitored and all parent ions were in the protonated state $[\mathrm{M}+\mathrm{H}]^{+}$. MRM transitions used for quantification were: $m / z \quad 313>285 ; 315>259 ; 329>243 ; 331>313$ for AFB1, AFB2, AFG1, AFG2, while confirmatory transitions were: $m / z \quad 313>241 ; 315>287 ; 329>259 ; 331>245$. The capillary voltage was $3.5 \mathrm{kV}$, the source temperature was $150{ }^{\circ} \mathrm{C}$, and the desolvation gas temperature was $400{ }^{\circ} \mathrm{C}$. The desolvation gas flow was $650 \mathrm{~L} \mathrm{~h}^{-1}$, while the cone gas flow was $10 \mathrm{~L} \mathrm{~h}^{-1}$ (both nitrogen). Collision-induced dissociation was performed using argon as the collision gas at a pressure of $3.7 \cdot 10^{-3} \mathrm{mbar}$ in the collision cell. The MassLynx and TargetLynx software (v. 4.1., Waters, USA) were used for the instrument control, data acquiring, and processing. Blank YES medium was spiked with the aflatoxin standard solution at a concentration of $10 \mathrm{ng} \mathrm{mL}^{-1}$ for recovery estimation, which was $92 \%$ for all aflatoxins. Instrumental limits of detection (LOD) were $0.15 \mathrm{ng} \mathrm{mL}^{-1}$, and the limits of quantification (LOQ) were $0.5 \mathrm{ng} \mathrm{mL}^{-1}$ for all aflatoxins.

\section{Aspergillus flavus NRRL 3251 oxidative status analysis}

Fungal cell oxidative status analysis included the determination of antioxidant enzyme activities, as well as 
the amount of lipid peroxides in the extracts of lyophilised A. flavus NRRL 3251 mycelia. The extracts for the enzyme activity determination were prepared by mixing $32 \mathrm{mg}$ of lyophilised mycelia and $1 \mathrm{~mL}$ of ice cold extraction buffer (50 mM potassium phosphate buffer, $\mathrm{pH}$ 7.0, containing $1 \mathrm{mM}$ EDTA-2Na). Extraction was performed during $20 \mathrm{~min}$ at $4{ }^{\circ} \mathrm{C}$ by vortexing, every $5 \mathrm{~min}$ for 30 seconds. The extracts were centrifuged $\left(15000 \mathrm{~g} / 4{ }^{\circ} \mathrm{C} / 20 \mathrm{~min}\right)$ (Heraeus, Germany) and used for the antioxidant enzyme activity determination. For thiobarbituric acid reactive substances (TBARS) assay, the same extraction procedure was used, but the extraction buffer additionally contained $100 \mathrm{mg} \mathrm{mL}^{-1}$ of TCA.

The activity of superoxide dismutase (SOD; EC 1.15.1.1) was determined by xanthine/xanthine oxidase/ NBT assay at $505 \mathrm{~nm}$ according to Angelova et al. (2005) (15). The catalase (CAT; EC 1.11.1.6) activity was determined according to Reverberi et al. (16) using the spectrophotometric method at $240 \mathrm{~nm}$, while the glutathione peroxidase (GPX; EC 1.11.1.9) activity assay was performed according to Esworthy et al. (17) using the spectrophotometric method at $340 \mathrm{~nm}$. Lipid peroxides (TBARS) were determined using the spectrophotometric method at $535 \mathrm{~nm}$ according to Luschak and Gospodaryov (18).

\section{Statistical analysis}

All data are presented as the mean value \pm SEM of three independent determinations from three separate experiments. For all experiments, datasets of the treated samples of different concentration and control samples were compared using the nonparametric statistics method Kruskal-Wallis ANOVA from the programme package Statistica 12.0 (StatSoft, USA). When the $\mathrm{p}$ value was $<0.05$, the differences were considered significant.

\section{RESULTS AND DISCUSSION}

The present study examined the antifungal and antiaflatoxigenic activity of two series of coumarinyl thiosemicarbazides (Figure 1) against A. flavus NRRL 3251. In the one class of coumarinyl thiosemicarbazides, coumarin core was substituted in position 7 (compounds 1-3, 5 and 11), while in the other one the core was substituted in position 4 (compounds 6-10, 12-13). The antifungal and antiaflatoxigenic activities were determined after $72 \mathrm{~h}$ of mycelia growth. This was based on preliminary experiments between 24 and $168 \mathrm{~h}$ of growth, showing that values obtained at $72 \mathrm{~h}$ are reliable for comparison. The effect of coumarinyl thiosemicarbazides was tested at $0.1,1$, and $10 \mu \mathrm{g} \mathrm{mL}^{-1}$. The final concentration of DMSO in growth media was $0.1 \%$, since preliminary experiments showed a significant effect of $1 \%$ DMSO on aflatoxin production. At this concentration, the aflatoxin content was reduced by $80 \%$ but without any effect on mycelial growth.
Coumarinyl thiosemicarbazides slightly inhibited fungal growth at the tested concentrations (Table 1). Among the tested compounds, compound 1 or 2-(2-((4-methyl-2ox o- $2 H$-chromen- 7 -yl ) oxy ) a cetyl $)-\mathrm{N}-(2,4,6$ trichlorophenyl)hydrazine-1-carbothioamide exhibited the highest antifungal activity of $45.86 \%$. In general, for both series of coumarinyl thiosemicarbazides, compounds with aromatic substituents showed a better antifungal activity than those with methyl and ethyl substituents. However, comparison among the series showed that coumarinyl derivatives substituted in position 7 possess a better antifungal activity than those substituted in position 4 (Table 1), indicating that the free hydroxyl group in position 7 is not of great importance for this kind of activity. Therefore, further development of coumarinyl thiosemicarbazides with coumarin core at position 7 substituted with various aromatic substituents, as potential antifungals, might be of interest.

Determination of antiaflatoxigenic activity of coumarinyl thiosemicarbazides (Table 2), revealed that compound 3, a coumarin substituted in position 7 and possessing 4-chlorophenyl substituent, $\mathrm{N}$-(4-chlorophenyl)2-(2-((4-methyl-2-oxo-2H-chromen-7-yl)oxy)acetyl) hydrazine-1-carbothioamide, completely inhibits aflatoxin production at the concentration of $10 \mu \mathrm{g} \mathrm{mL}^{-1}$. While this compound exhibited a considerable antiaflatoxigenic activity, its antifungal activity was quite moderate at the concentration of $11.99 \%$. However, it should be pointed out that the compound 3 at lower concentrations of 0.1 and $1 \mu \mathrm{g} \mathrm{mL}^{-1}$ induced an aflatoxin production of 71.57 and $84.96 \%$. Moderate antiaflatoxigenic activity was found for the compound 10 and slight for the compounds 6 and 12 . The compound 10 (trichlorophenyl substituent, position 4), 2-(2-(7-hydroxy-2-oxo-2H-chromen-4-yl)acetyl)-N-(2,4,6trichlorophenyl)hydrazine-1-carbothioamide was found to inhibit aflatoxin production $(65.51 \%)$ at the highest concentration $\left(10 \mu \mathrm{g} \mathrm{mL}^{-1}\right)$, while at lower concentrations there was only a slight induction of aflatoxin production. The same compound, at its highest concentration, exhibited slight antifungal activity and inhibited mycelia growth by $19.51 \%$. The compound 12, 2-(2-(7-hydroxy-2-oxo- $2 \mathrm{H}$ chromen-4-yl)acetyl)- $N$-phenylhydrazine- 1 carbothioamide, (phenyl substituent, position 4) showed antiaflatoxigenic activity at the concentrations of 0.1 and $1 \mu \mathrm{g} \mathrm{mL} \mathrm{m}^{-1}$, inhibiting aflatoxin production by 28.73 and $25.98 \%$, respectively, while its highest concentration induced production of aflatoxins. However, at its highest concentration, the compound 12 inhibited mycelial growth of $16.94 \%$, while at the lowest concentrations no antifungal activity was found. Antiaflatoxigenic activity of $26.78 \%$ was found for the compound 6 (ethyl substituent, position 4), $\mathrm{N}$-ethyl-2-(2-(7-hydroxy-2-oxo-2H-chromen-4-yl) acetyl)hydrazine-1-carbothioamide, at the concentration of $1 \mu \mathrm{g} \mathrm{mL} \mathrm{m}^{-1}$. At the same concentration of $1 \mu \mathrm{g} \mathrm{mL}^{-1}$, this compound exhibited a low antifungal activity (6.72\%). Besides the observed antiaflatoxigenic activity, several 


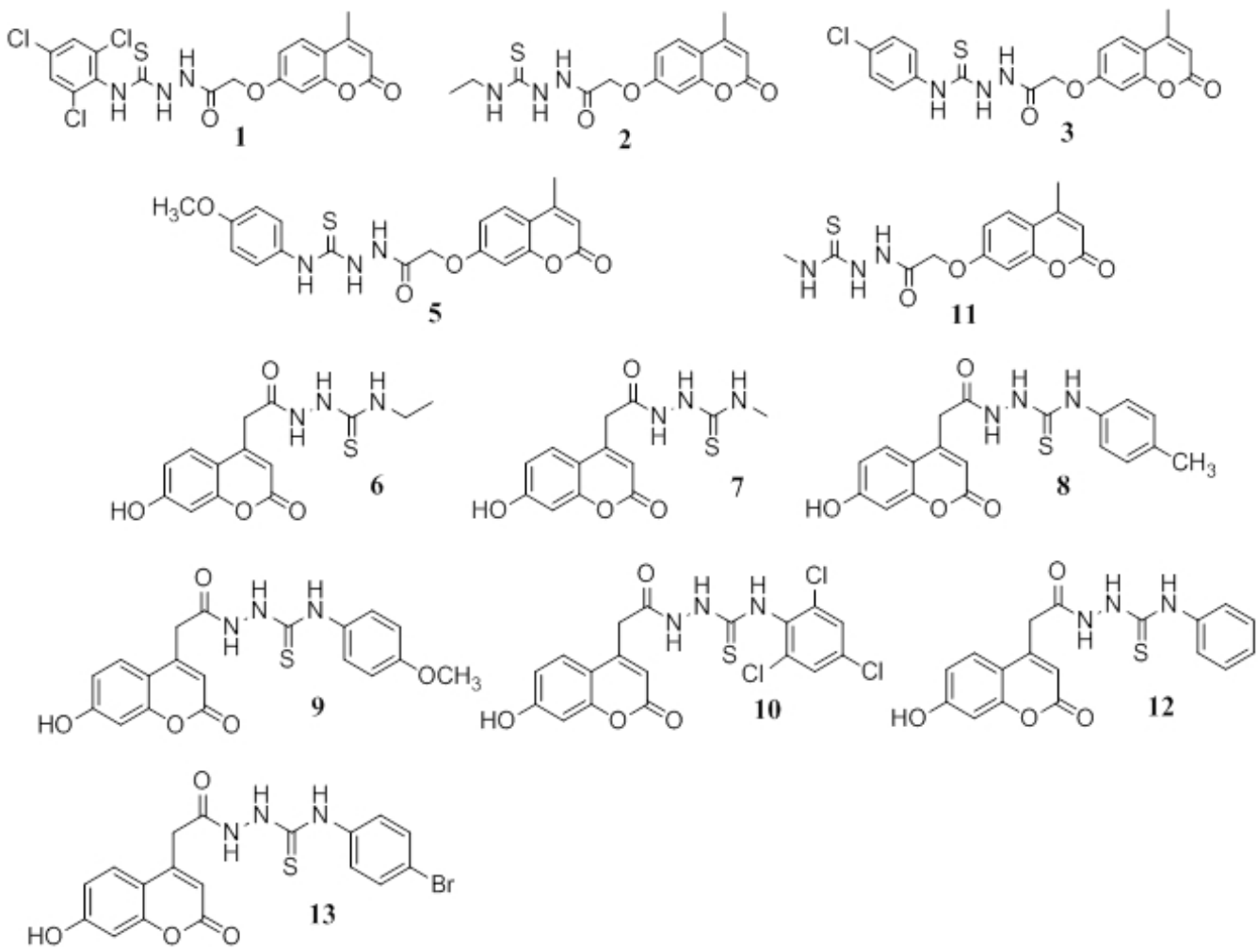

Figure 1 The tested coumarinyl thiosemicarbazides

coumarinyl thiosemicarbazide compounds were found to greatly enhance aflatoxin production (Table 2). The compound 1, 2-(2-((4-methyl-2-oxo-2H-chromen-7-yl)oxy) acetyl)- $N-(2,4,6$-trichlorophenyl)hydrazine- 1 carbothioamide, exhibiting the greatest antifungal activity, was also the most prominent inductor of aflatoxin production, causing an increase of $69.68 \%$ in the aflatoxin content at the concentration of $1 \mu \mathrm{g} \mathrm{mL}^{-1}$.
Taken together, the results on antifungal and antiaflatoxigenic activity of the synthesised compounds show that the compounds $3,6,10$, and 12 possess significant antiaflatoxigenic and slight antifungal activities. The observed results are in accordance with the observation of Degola et al. (1), who found that some synthetic thiosemicarbazones displayed a prominent effect on mycotoxin synthesis, rather than on fungal growth.

Table 1 Antifungal activity of coumarinyl thiosemicarbazides with coumarin core substituted in position 7 (compounds 1-5 and 11) and in position 4 (compounds 6-10, 12-13). Results are represented as the mean \pm SEM from three separate experiments

\begin{tabular}{lccc} 
& \multicolumn{3}{c}{ Mycelia growth [g d.m.w.] } \\
\cline { 2 - 4 } Compound & $\mathbf{0 . 1}$ & $\mathbf{1}$ & $\mathbf{1 0}$ \\
\cline { 2 - 4 } & & $0.1938 \pm 0.0127^{\mathrm{a}}$ \\
\hline Control & $0.1999 \pm 0.0027^{\mathrm{a}}$ & $0.1466 \pm 0.0074^{\mathrm{b}}$ & $0.1200 \pm 0.0030^{\mathrm{b}}$ \\
\hline 1 & $0.2020 \pm 0.0093^{\mathrm{a}}$ & $0.2075 \pm 0.0039^{\mathrm{a}}$ & $0.1910 \pm 0.0122^{\mathrm{a}}$ \\
\hline 2 & $0.1751 \pm 0.0163^{\mathrm{a}}$ & $0.1413 \pm 0.0023^{\mathrm{b}}$ & $0.1706 \pm 0.0036^{\mathrm{a}}$ \\
\hline 3 & $0.1597 \pm 0.0025^{\mathrm{a}}$ & $0.1600 \pm 0.0067^{\mathrm{a}}$ & $0.1864 \pm 0.0055^{\mathrm{a}}$ \\
\hline 5 & $0.1887 \pm 0.0128^{\mathrm{a}}$ & $0.1808 \pm 0.0333^{\mathrm{a}}$ & $0.1765 \pm 0.0036^{\mathrm{a}}$ \\
\hline 6 & $0.1939 \pm 0.0098^{\mathrm{a}}$ & $0.2131 \pm 0.0143^{\mathrm{a}}$ & $0.1976 \pm 0.0006^{\mathrm{a}}$ \\
\hline 7 & $0.1668 \pm 0.0006^{\mathrm{a}}$ & $0.1914 \pm 0.0040^{\mathrm{a}}$ & $0.1444 \pm 0.0033^{\mathrm{b}}$ \\
\hline 9 & $0.1977 \pm 0.0099^{\mathrm{a}}$ & $0.1514 \pm 0.0023^{\mathrm{a}}$ & $0.1622 \pm 0.0161^{\mathrm{a}}$ \\
\hline 10 & $0.1888 \pm 0.0108^{\mathrm{a}}$ & $0.1578 \pm 0.0082^{\mathrm{a}}$ & $0.1560 \pm 0.0201^{\mathrm{a}}$ \\
\hline 12 & $0.1824 \pm 0.0051^{\mathrm{a}}$ & $0.1978 \pm 0.0076^{\mathrm{a}}$ & $0.2038 \pm 0.0029^{\mathrm{a}}$ \\
\hline 13 & $0.2040 \pm 0.0070^{\mathrm{a}}$ & $0.2049 \pm 0.0083^{\mathrm{a}}$ & $0.1610 \pm 0.0142^{\mathrm{a}}$ \\
\hline
\end{tabular}

*no data

${ }^{a}$ statistically not significant difference

${ }^{b}$ statistically significant difference 
Table 2 Antiaflatoxigenic activity of coumarinyl thiosemicarbazides with coumarin core substituted in position 7 (compounds 1-5 and 11) and in position 4 (compounds 6-10, 12-13). Results are represented as the mean \pm SEM from three separate experiments

\begin{tabular}{|c|c|c|c|}
\hline \multirow{3}{*}{ Compound } & \multicolumn{3}{|c|}{ Aflatoxin B1 production [ng $\mathrm{mL}^{-1} / \mathrm{g}$ d.m.w.] } \\
\hline & \multicolumn{3}{|c|}{ Tested concentration $\left[\mu \mathrm{g} \mathrm{mL}^{-1}\right]$} \\
\hline & 0.1 & 1 & 10 \\
\hline Control & \multicolumn{3}{|c|}{$1270.95 \pm 42.49^{\mathrm{a}}$} \\
\hline 1 & $941.95 \pm 231.43^{b}$ & $2155.50 \pm 326.43^{b}$ & $1761.7 \pm 209.78^{\mathrm{a}}$ \\
\hline 2 & $1049.44 \pm 304.621^{\mathrm{a}}$ & $1831.44 \pm 713.19^{b}$ & $1354.88 \pm 310.45^{\mathrm{a}}$ \\
\hline 3 & $2179.94 \pm 68.95^{b}$ & $2343.94 \pm 141.71^{\mathrm{b}}$ & $<\mathrm{LOD}^{\mathrm{b}}$ \\
\hline 5 & $1189.01 \pm 352.45^{\mathrm{a}}$ & $1486.69 \pm 331.47^{\mathrm{a}}$ & $921.85 \pm 110.62^{\mathrm{a}}$ \\
\hline 6 & $1837.51 \pm 455.70^{\mathrm{b}}$ & $930.56 \pm 141.97^{b}$ & $1079.08 \pm 170.30^{\mathrm{a}}$ \\
\hline 7 & $1453.96 \pm 165.45^{\mathrm{a}}$ & $1535.62 \pm 473.86^{\mathrm{a}}$ & $1306.74 \pm 345.44^{\mathrm{a}}$ \\
\hline 8 & $1466.60 \pm 430.17^{\mathrm{a}}$ & $1260.57 \pm 159.57^{\mathrm{a}}$ & $1513.1 \pm 315.99^{\mathrm{a}}$ \\
\hline 9 & $1486.88 \pm 226.17^{\mathrm{a}}$ & $1358.65 \pm 237.18^{\mathrm{a}}$ & $1594.54 \pm 459.51^{\mathrm{a}}$ \\
\hline 10 & $1491.62 \pm 69.40^{\mathrm{a}}$ & $1844.30 \pm 232.27^{\mathrm{b}}$ & $483.75 \pm 279.87^{b}$ \\
\hline 11 & $837.32 \pm 55.43^{b}$ & $1189.28 \pm 327.81^{\mathrm{a}}$ & $1039.16 \pm 41.23^{\mathrm{a}}$ \\
\hline 12 & $905.76 \pm 56.83^{b}$ & $948 \pm 280.08^{b}$ & $1882.67 \pm 322.48^{\mathrm{a}}$ \\
\hline 13 & $1338.83 \pm 365.42^{\mathrm{a}}$ & $960.28 \pm 164.69^{\mathrm{a}}$ & $*$ \\
\hline
\end{tabular}

*no data

${ }^{a}$ statistically not significant difference

${ }^{b}$ statistically significant difference

According to Holmes et al. (19), one of the possible reasons for the antiaflatoxigenic activity of coumarins might be their structural similarity with aflatoxin intermediates, causing competitive inhibition of enzymes involved in aflatoxin biosynthesis. However, the exact mechanism of coumarin influence on aflatoxin biosynthesis is still unknown. Another possible reason for aflatoxin production inhibition by coumarins can be their considerable antioxidant activity. Namely, many of aflatoxin production inhibitors possess antioxidant activity that could interfere with aflatoxin production due to: a) decreased oxidative stress within fungal cells, b) inhibition of mitochondrial and/or peroxisomal fatty acid $\beta$-oxidation, and/or c) consumption of reduced NADPH necessary for polyketide pathway in aflatoxin biosynthesis (19).

It is well established that increased oxidative stress within fungal cells triggers aflatoxin synthesis (20-22). Thus, a decrease in fungal cell oxidative stress caused by exogenously added antioxidants might be one of the possible reasons for decreased aflatoxin production. Since Degola et al. (1) reported that some of the antiaflatoxigenic synthetic thiosemicarbazone derivatives possess high antioxidant activity, we speculated that the compounds 3 , 6,10 , and 12 as antioxidants might affect aflatoxin inhibition production by modulating oxidative stress within fungal cells.

The determination of antioxidant activity of the compounds $3,6,10$, and 12 by the DPPH method (Table 3 ) shows that the compounds 3 and 10 possess significant DPPH scavenging activity of 69.9 and $56.7 \%$, respectively. This could be one of the reasons for the observed significant antiaflatoxigenic activity of the compounds 3 and 10 (Table 2). However, the compounds 6 and 12 , which have a significant antioxidant activity (Table 3), showed a much lower antiaflatoxigenic activity. This is in agreement with Holmes et al. (19) who stated that the antioxidant activity of exogenously added antioxidants can neither be a guarantee of their action nor a predictor of their impact on the aflatoxin production by A. flavus cell. Similar was found for fungal oxidative status modulation (Table 4) where no significant dose-dependent effect of compounds could be established. However, at the highest concentration, the compounds 3 and 10 caused elevated levels of SOD and GPX, and a decreased CAT level, modulating oxidative state within fungal cells. This could be an additional reason for the observed decrease in aflatoxin production (Table 2). On the contrary, the compounds 6 and 12 were not found to be significant oxidative status modulators or aflatoxin production inhibitors.

\section{CONCLUSION}

In this preliminary study, antifungal and antiaflatoxigenic activity of two series of coumarinyl thiosemicarbazides were examined, one with the coumarin core substituted in position 7 (compounds 1-5 and 11) and another substituted

Table 3 DPPH* radical-scavenging activity of coumarinyl thiosemicarbazides, $\mathrm{N}$-(4-chlorophenyl)-2-(2-((4-methyl-2-oxo2H-chromen-7-yl)oxy)acetyl)hydrazine-1-carbothioamide (3), $\mathrm{N}$-ethyl-2-(2-(7-hydroxy-2-oxo-2H-chromen-4-yl)acetyl) hydrazine-1-carbothioamide (6), 2-(2-(7-hydroxy-2-oxo-2Hchromen-4-yl)acetyl)-N-(2,4,6-trichlorophenyl)hydrazine-1carbothioamide (10) and 2-(2-(7-hydroxy-2-oxo-2H-chromen-4yl)acetyl)- $N$-phenylhydrazine-1-carbothioamide (12) (0.1 mM)

\begin{tabular}{cc}
\hline Compound & $\begin{array}{c}\text { DPPH'- scavenging } \\
\text { activity (\%) }\end{array}$ \\
\hline 3 & 69.9 \\
\hline 6 & 37.5 \\
\hline 10 & 56.7 \\
\hline 12 & 69.5 \\
\hline
\end{tabular}


Table 4 Oxidative stress markers in extracts of A. flavus NRRL 3251 mycelia after application of coumarinyl thiosemicarbazides with coumarin core substituted in position 7 (compound 3) and in position 4 (compounds 6, 10, and 12) at concentrations of 0.1,1, and

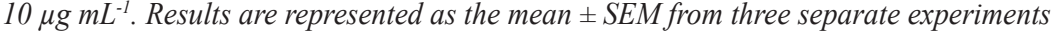

\begin{tabular}{|c|c|c|c|c|c|c|}
\hline \multirow{3}{*}{ Compound } & \multicolumn{3}{|c|}{$\begin{array}{l}\text { TBARS pmol } \\
\text { [mg d.m.w.] }\end{array}$} & \multicolumn{3}{|c|}{$\begin{array}{c}\text { SOD } \\
{\left[\mathbf{U}^{-1} \mathbf{~ g}^{-1}\right]}\end{array}$} \\
\hline & \multicolumn{3}{|c|}{ Tested concentration $\left[\mu \mathrm{g} \mathrm{mL} \mathrm{L}^{-1}\right]$} & \multicolumn{3}{|c|}{ Tested concentration $\left[\mu \mathrm{g} \mathrm{mL} \mathrm{m}^{-1}\right]$} \\
\hline & 0.1 & 1 & 10 & 0.1 & 1 & 10 \\
\hline 3 & $24.84 \pm 0.25^{\mathrm{b}}$ & $32.45 \pm 0.38^{\mathrm{a}}$ & $34.66 \pm 0.06^{\mathrm{a}}$ & $43.06 \pm 0.43^{\mathrm{a}}$ & $31.99 \pm 0.52^{\mathrm{b}}$ & $55.10 \pm 1.73^{\mathrm{b}}$ \\
\hline 6 & $40.67 \pm 0.05^{\mathrm{b}}$ & $36.66 \pm 0.20^{\mathrm{a}}$ & $34.46 \pm 0.35 \mathrm{a}$ & $42.30 \pm 0.63^{\mathrm{a}}$ & $40.10 \pm 1.48^{\mathrm{a}}$ & $41.42 \pm 0.79^{\mathrm{a}}$ \\
\hline 10 & $38.26 \pm 0.20^{\mathrm{b}}$ & $52.48 \pm 0.21^{\mathrm{b}}$ & $47.48 \pm 0.17^{\mathrm{b}}$ & $49.69 \pm 1.49^{b}$ & $35.84 \pm 0.16^{\mathrm{a}}$ & $52.33 \pm 2.43^{b}$ \\
\hline 12 & $32.05 \pm 0.22^{\mathrm{a}}$ & $34.05 \pm 0.16^{\mathrm{a}}$ & $30.85 \pm 0.17^{\mathrm{a}}$ & $40.41 \pm 0.88^{\mathrm{a}}$ & $41.74 \pm 0.30^{\mathrm{a}}$ & $48.60 \pm 0.91^{\mathrm{b}}$ \\
\hline \multirow[t]{4}{*}{ Control } & \multicolumn{3}{|c|}{$31.25 \pm 0.22^{\mathrm{a}}$} & \multicolumn{3}{|c|}{$39.90 \pm 2.39^{\mathrm{a}}$} \\
\hline & \multicolumn{3}{|c|}{$\begin{array}{c}\text { CAT } \\
{\left[\mathbf{U ~ m g}^{-1}\right]}\end{array}$} & \multicolumn{3}{|c|}{$\begin{array}{c}\text { GPX } \\
{\left[\mathbf{m U} \mathbf{~ m g}^{-1}\right]}\end{array}$} \\
\hline & \multicolumn{3}{|c|}{ Tested concentration $\left[\mu \mathrm{g} \mathrm{mL}^{-1}\right]$} & \multicolumn{3}{|c|}{ 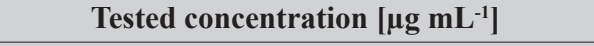 } \\
\hline & 0.1 & 1 & 10 & 0.1 & 1 & 10 \\
\hline 3 & $30.25 \pm 0.46^{\mathrm{a}}$ & $18.02 \pm 0.12^{b}$ & $17.63 \pm 0.21^{\mathrm{b}}$ & $8.33 \pm 0.31^{\mathrm{a}}$ & $13.62 \pm 1.43^{\mathrm{a}}$ & $13.85 \pm 0.18^{\mathrm{b}}$ \\
\hline 6 & $28.62 \pm 0.28^{\mathrm{a}}$ & $36.82 \pm 0.38^{\mathrm{a}}$ & $29.56 \pm 0.18^{\mathrm{a}}$ & $16.18 \pm 0.14^{\mathrm{b}}$ & $16.49 \pm 0.66^{\mathrm{b}}$ & $14.77 \pm 0.13^{b}$ \\
\hline 10 & $30.04 \pm 0.23^{\mathrm{a}}$ & $16.74 \pm 0.03^{b}$ & $18.39 \pm 0.24^{b}$ & $12.63 \pm 0.81^{\mathrm{a}}$ & $13.29 \pm 0.14^{\mathrm{b}}$ & $17.73 \pm 0.28^{\mathrm{b}}$ \\
\hline 12 & $40.27 \pm 0.02^{\mathrm{b}}$ & $36.13 \pm 0.31^{\mathrm{a}}$ & $35.78 \pm 0.71^{\mathrm{a}}$ & $14.97 \pm 0.38^{b}$ & $14.37 \pm 0.51^{\mathrm{b}}$ & $18.63 \pm 0.24^{\mathrm{b}}$ \\
\hline Control & \multicolumn{3}{|c|}{$31.05 \pm 0.51^{\mathrm{a}}$} & \multicolumn{3}{|c|}{$10.53 \pm 0.71^{\mathrm{a}}$} \\
\hline
\end{tabular}

${ }^{a}$ statistically not significant difference

${ }^{b}$ statistically significant difference

in position 4 (compounds $6-10,12-13$ ). The substituted coumarinyl thiosemicarbazides (compounds 3, 6, 10, and 12) were found to be slight antifungal and moderate antiaflatoxigenic agents, with the compound 3 exhibiting complete inhibition of aflatoxin production. Evaluation of the fungal cell oxidative status in mycelia exposed to the compounds 3 and 10 indicates that the antiaflatoxigenic activity could be related to its antioxidant activity and subsequent oxidative stress response modulation. Further investigation of substituted coumarinyl thiosemicarbazides and their effect on antifungal and antiaflatoxigenic activities, as well as the mechanism of their action, is of interest. That is the first step towards a potential application of the tested compounds in food industry, agriculture, or medicine.

\section{REFERENCES}

1. Degola F, Morcia C, Bisceglie F, Mussi F, Tumino G, Ghizzoni R, Pelosi G, Terzi V, Buschini A, Restivo FM, Lodi T. In vitro evaluation of the activity of thiosemicarbazone derivatives against mycotoxigenic fungi affecting cereals. Int J Food Microbiol 2015;200:104-11. doi: 10.1016/j. ijfoodmicro.2015.02.009

2. Zani C, Restivo FM, Carcelli M, Feretti D, Pelosi G, Rogolino D, Degola F, Galati S, Bisceglie F, Buschini A. A biotechnological approach for the development of new antifungal compounds to protect the environment and the human health. J Public Health Res 2015;4:613. doi: 10.4081/ jphr.2015.613

3. Battilani P, Toscano P, Van der Fels-Klerx HJ, Moretti A, Camardo Leggieri M, Brera C, Rortais A, Goumperis T, Robinson T. Aflatoxin B1 contamination in maize in Europe increases due to climate change. Sci Rep 2016;12;6:24328. doi: 10.1038/srep24328

4. Radulović N, Stojanović G, Vukićević R, Dekić V, Dekić B, Palić R. New 3,4-annelated coumarin derivatives: synthesis, antimicrobial activity, antioxidant capacity, and molecular modeling. Monatsh Chem Chem Mon 2006;137:1477-86. doi: 10.1007/s00706-006-0537-6

5. Soltani S, Dianat S, Sardari S. Forward modeling of the coumarin antifungals; SPR/SAR based perspective. Avicenna J Med Biotechnol 2009;1(2):95-103. PMC 3558124

6. Pelosi G. Thiosemicarbazone metal complexes: From structure to activity. The Open Crystallography Journal 2010;3:16-28 [displayed 10 February 2017]. Avaliable at http://benthamopen.com/contents/pdf/TOCRYJ/ TOCRYJ-3-16.pdf

7. Pishawikar AS, More HN. Synthesis, docking and in-vitro screening of mannich bases of thiosemicarbazide for antifungal activity. Arabian Journal of Chemistry 2013 [displayed 10 February 2017]. Avaliable at http://www.sciencedirect. com/science/article/pii/S1878535213003560

8. Cardenas-Ortega NC, Perez-Gonzalez C, Zavala-Sanchez MA, Hernandez-Ramirez AB, Perez-Gutierrez S. Antifungal activity of seselin in protecting stored maize from Aspergillus flavus. Asian J Plant Sci 2007;6:712-4. doi: 10.3923/ ajps.2007.712.714

9. Mishra BB, Singh DD, Kishore N, Tiwari VK, Tripathi V. Antifungal constituents isolated from the seeds of Aegle marmelos. Phytochemistry 2010;71:230-4. doi: 10.1016/j. phytochem.2009.10.013

10. Šarkanj B, Molnar M, Čačić M, Gille L. 4-Methyl-7hydroxycoumarin antifungal and antioxidant activity enhancement by substitution with thiosemicarbazide and thiazolidinone moieties. Food Chem 2013;139:488-95. doi: 10.1016/j.foodchem.2013.01.027

11. Guerra FQS, Aquino de Araújo RS, Pereira de Sousa J, de Oliveira Pereira F, Mendonça-Junior FJB, Barbosa-Filho JM, 
de Oliveira Lima E. Evaluation of antifungal activity and mode of action of new coumarin derivative, 7-Hydroxy-6nitro-2H-1-benzopyran-2-one, against Aspergillus spp. Evid Based Complement Alternat Med 2015;2015:925096. doi: 10.1155/2015/925096

12. Chanda A, Roze LV, Kang S, Artymovich KA, Hicks GR, Raikhel NV, Calvo AM, Linz JE. A key role for vesicles in fungal secondary metabolism. Proc Natl Acad Sci USA 2009;106:19533-8. doi: 10.1073/pnas.0907416106

13. Chanda A, Roze LV, Linz JE. A possible role for exocytosis in aflatoxin export in Aspergillus parasiticus. Eukaryot Cell 2010;9:1724-7. doi: 10.1128/EC.00118-10

14. Yu J. Current understanding on aflatoxin biosynthesis and future perspective in reducing aflatoxin contamination. Toxins 2012;4:1024-57. doi: 10.3390/toxins4111024

15. Angelova MB, Pashova SB, Spasova BK, Vassilev S V, Slokoska LS. Oxidative stress response of filamentous fungi induced by hydrogen peroxide and paraquat. Mycol Res 2005;109:150-8. doi: 10.1017/S0953756204001352

16. Reverberi M, Fabbri AA, Zjalic S, Ricelli A, Punelli F, Fanelli C. Antioxidant enzymes stimulation in Aspergillus parasiticus by Lentinula edodes inhibits aflatoxin production. Appl Microbiol Biotechnol 2005;69:207-15. doi: 10.1007/ s00253-005-1979-1

17. Esworthy RS, Chu FF, Doroshow JH. Analysis of glutathionerelated enzymes. In: Costa LG, Hodgson E, Lawrence DA,
Reed DJ, Greenlee WF, editors. Current Protocols in Toxicology. Chapter 7. Assessment of the activity of antioxidant enzymes. New York (NY): John Wiley \& Sons; 2005. p. 7.1.1.-7.1.32.

18. Lushchak VI, Gospodaryov DV. Catalases protect cellular proteins from oxidative modification in Saccharomyces cerevisiae. Cell Biol Int 2005;29:187-92. doi: 10.1016/j. cellbi.2004.11.001

19. Holmes RA, Boston RS, Payne GA. Diverse inhibitors of aflatoxin biosynthesis. Appl Microbiol Biotechnol 2008;78:559-72. doi: 10.1007/s00253-008-1362-0

20. Jayashree T, Subramanyam C. Oxidative stress a prerequisite for aflatoxin production by Aspergillus parasiticus. Free Radic Biol Med 2000;29:981-5. doi: 10.1016/S08915849(00)00398-1

21. Reverberi M, Ricelli A, Zjalic S, Fabbri AA, Fanelli C. Natural functions of mycotoxins and control of their biosynthesis in fungi. Appl Microbiol Biotechnol 2010;87:899-911. doi: 10.1007/s00253-010-2657-5

22. Reverberi M, Punelli M, Smith CA, Zjalić S, Scarpari M, Scala V, Cardinali G, Aspite N, Pinzari F, Payne GA, Fabbri AA, Fanelli C. How peroxisomes affect aflatoxin biosynthesis in Aspergillus flavus. PLoS One 2012;7:e48097. [displayed 19 October 2012]. Available at http://journals.plos.org/ plosone/article?id=10.1371/journal.pone.0048097

\section{Antifungalno i antiaflatoksikogeno djelovanje kumarinil tiosemikarbazida na plijesan Aspergillus flavus NRRL 3251}

Ispitano je antifungalno i antiaflatoksikogeno djelovanje dviju serija kumarinskih tiosemikarbazida na plijesan Aspergillus flavus NRRL 3251. Plijesan je uzgojena u YES mediju tijekom 72 sata na $29^{\circ} \mathrm{C}$ u prisutnosti kumarinskih tiosemikarbazida, koncentracija $0,0,1,1 \mathrm{i} 10 \mu \mathrm{g} \mathrm{mL}^{-1}$, jedne serije gdje je kumarin supstituiran u položaju 4 i druge sa supstitucijom $\mathrm{u}$ položaju 7 kumarinske jezgre. Antifungalna aktivnost određena je mjerenjem mase suhog micelija, a sadržaj aflatoksina B1 određen je u YES mediju dilute and shoot LC/MS-MS metodom. Za određivanje markera oksidativnoga statusa $\mathrm{u}$ miceliju A. flavus NRRL 3251 koristili su se standardni biokemijski testovi (TBARS, SOD, CAT i GPX). Rezultati su pokazali da tiosemikarbazidi na kumarinu supstituiranom u položaju 7 imaju bolju antifungalnu i antimikotoksigenu aktivnost nego oni s kumarinom supstituiranom u položaju 4. Od ispitivanih spojeva valja istaknuti spoj 3, $N$-(4-klorofenil)2-(2-((4-metil-2-okso-2H-kromen-7-il)oksi)acetil)hidrazin-1-karbotioamid, koji je pri koncentraciji $10 \mu \mathrm{g} \mathrm{mL}{ }^{-1}$ potpuno inhibirao produkciju aflatoksina. Iz dobivenih rezultata može se pretpostaviti da je vjerojatni uzrok inhibicije produkcije aflatoksina oksidacijski stres uzrokovan ispitanim spojevima. 